\title{
THE AHP IMPLEMENTATION IN STRATEGIC MANAGEMENT PROCESS - A CASE STUDY OF DECISION MAKING IN POLISH LOCAL ADMINISTRATION
}

\begin{abstract}
Modern economy requires continuous improvement of the management process. This applies not only to business, but also to public administration. It is necessary to search for methods, improving the quality of management, including optimization of decision-making processes. One of such decision support methods is the Analytic Hierarchy Process (AHP), proposed by American mathematician, T.L. Saaty in the 70's. Since then, this method has been widely used in practice. This paper reports the process of building and analyzing the AHP model, which supports a local government (District Office) in identifying priority factors of strategic management. The implementation took place in one of the districts of Southern Poland, Nowy Targ. The model refers to strategic management of local development understood as changes in an endogenous potential of the region. It is built by four main criteria: potential of society, potential of the economy, potential of the environment, and potential of institutions (local government). Each criterion consists of several influencing factors (subcriteria). The surveyed group involved 14 decision makers employed in the District Office in Nowy Targ. All of them were responsible for making key decisions in planning and implementation of district strategies. The AIP (Aggregation of Individual Priorities) procedure was used to aggregate individual AHP results. The priorities show that the most important factors influencing local development at the district level are Entrepreneurship, Tourist attractions, Demographic potential, Innovation in business, Clean environment and Competencies of the local government employees. These aspects should be the main directions for strategic interventions in the years 2015-2022.

Keywords: public administration, strategic management, local development, AHP.
\end{abstract}

\section{INTRODUCTION}

The introduction of the mechanism of local and regional governance in Poland was one of the most important episodes for the first post-communist government after a transition period in $1989 / 1990^{4}$. Currently, the basic framework for the functioning of territorial system has

\footnotetext{
${ }^{1}$ Jacek Strojny, PhD, Department of Economics, Rzeszow University of Technology, Rzeszow, Av. Powstancow Warszawy 12, +48 17865 1403, corresponding author, e-mail: jstrojny@prz.edu.pl

2 Anna Prusak, PhD, Department of Quality Management, Krakow University of Economics, Krakow, Rakowicka St. 27, 31-510 Krakow, Poland; e-mail: anna.prusak@uek.krakow.pl, phone: +48 122937516 .

${ }^{3}$ Monica Garcia Melon, PhD, Department of Projects Engineering, Universitat Polictecnica de Valencia, 46020 Valencia, Spain; e-mail: mgarciam@dpi.upv.es, phone: +34 626024604

4 A. Potoczek, Zarzadzanie jednostka terytorialna. Wybrane zagadnienia, Wydawnictwo Uczelniane Wyższej Szkoły Gospodarki, Bydgoszcz 2013.
} 
been settled in the administrative structure introduced by the reform in 1999. It identifies a central government and territorial governments: regional (voivodships) and local (districts and municipalities) $)^{5}$. Development of regional and local governance resulted in a progressive increase of responsibilities of local governments, which have been equipped with new competencies. Obviously, along with the new tasks the government has greater opportunities to generate income, as for example the increasing share of taxes PIT (Personal Income Tax) and CIT (Corporate Income Tax) ${ }^{6}$.

The growing importance of local governments increases pressure on the efficiency and effectiveness of their activities and development ${ }^{7}$. One of the fundamental problems that still has not been solved is the low efficiency of strategic management ${ }^{8}$. Nowadays, the long-term programming of development is very often detached from the conditions determining the implementation of the strategy. It results in a total or substantial detachment of strategic documents from operational management. Therefore, one of the key tasks of local and regional government is to improve the strategic management by increasing its coherence. This is particularly important in the context of the current programming period 2014-2020. The need for optimal use of the new EU funds while meeting the debt limit is a very big challenge for the entire public administration.

The implementation of decision support methods is one of the basic steps in the process of improving the quality of governance. One of such methods is the Analytic Hierarchy Process (AHP) (Saaty, 1980), the most widely used (by scientists and practitioners) approach supporting decision-making processes ${ }^{9}$. There has been no AHP study, which can be compared directly with the research reported in the current paper. However, the AHP has been applied in many fields to solve a wide range of decision problems ${ }^{10}$. Notably, the method has been used successfully in many commercial companies, including IBM and British Airways. The AHP was also used by the US Department of Defense to make important military decisions ${ }^{11}$.

The main advantages of this method are its simplicity and applicability to a wide range of decision problems. The goal of this paper is to build and analyze the AHP model, which support local governments in identifying priority factors of strategic management in the context of endogenous potential. This model allows structuring decision problems by presenting general and specific areas of potential intervention. Subsequently, it also determines the priority areas which require the greatest care in a given government unit at a time.

\footnotetext{
${ }^{5}$ Central Statistic Office, Area and population in the territorial profile in 2015, CSO, Methodology, Standards and Registers Department Warsaw 2015.

${ }^{6}$ Public Financial Act, Parliament, Warsaw 2009.

${ }^{7}$ B. Filipiak, Efektywność w zarzadzaniu finansami samorzqdowymi. Skutek kryzysu czy obiektywna konieczność?, Zeszyty Naukowe, Polskie Towarzystwo Ekonomiczne, (10), 2011, p. 223-236.

8 J. Strojny, Innowacyjne zarzadzanie regionem, powiatem $i$ gmina, Rzeszow University of Technology, Rzeszow 2012.

${ }^{9}$ A. Prusak, J. Strojny, P. Stefanów, Analityczny Proces Hierarchiczny (AHP) na skróty - kluczowe pojęcia i literatura, Humanities and Social Sciences, (4), 2014, p. 179-192.

10 O. S. Vaidya, S. Kumar, Analytic hierarchy process: An overview of applications, European Journal of Operational Research, 169(1), 2006, 1-29.

11 T.L. Saaty, Relative Measurement and Its Generalization in Decision Making. Why Pairwise Comparisons are Central in Mathematics for the Measurement of Intangible Factors The Analytic Hierarchy/Network Process, RACSAM (Revista de La Real Academia de Ciencias Exactes, Fisicas Y Naturales. Serie A. Matematicas), 102(2), 2008, p. 251-318.
} 


\section{THE CONTEXT OF STRATEGIC MANAGEMENT IN LOCAL AND REGIONAL DEVELOPMENT}

The term development is often regarded with positive changes in various dimensions of social and economic processes ${ }^{12}$. The adoption of such a broad perspective causes difficulties in measuring this phenomenon, and its unambiguous interpretation. Thus, it is useful to narrow the term development to the production capacity of the economic system. Consequently, the concept of economic growth should be understood as the process of increasing the productivity of the economic system. This point of view is typical for many economic approaches, but it is too broad for the presented research. Therefore, this article focuses mainly on endogenous growth models presented by i.a.: P.M. Romer ${ }^{13}$ or R.E. Lucas ${ }^{14}$. They assumed that the ability to generate production in the economic system (e.g. the region, district or municipality) is determined by the accumulation process of the capital (human and material) in the existing technological potential. Both of these approaches, as well as other concepts, e.g. by S. Rebelo $^{15}, \mathrm{Ph}$. Aghion and P. Howitt ${ }^{16}$, or O. Galor and D.N. Weil ${ }^{17}$, assumed the impact of endogenous potential on the production volumes. It means that the endogenous potential is limited mainly to the factors directly related to the process of production.

In this paper, a wider perspective was chosen: socioeconomic, not only an economic one. From the point of view of the local government, the processes determining the quality of life are very important. It means that a broader definition of development processes is needed for a complete strategic thinking. In the current work, this term is understood as positive changes in all areas of endogenic potential, specifically: society, economy, environment and local government institutions. Presently, such socioeconomic approach is very common in the analysis of territorial development. It could be found for example in research like RCI (Regional Competitiveness Index) ${ }^{18}$ or other research and theoretical models provided by economists and sociologists ${ }^{19}$.

\footnotetext{
${ }^{12}$ More in: K. Kompa, Budowa mierników agregatowych do oceny poziomu rozwoju spotecznogospodarczego, Zeszyty Naukowe SGGW Ekonomika i Organizacja Gospodarki Żywnościowej, 74, 2009.

${ }^{13}$ P.M. Romer, The Origins of Endogenous Growth, Journal of Economic Perspectives, 8, 1994, p. 3-22.

${ }^{14}$ R.E. Lucas, On the Mechanics of Economic Development, Journal of Monetary Economics, 22, 1988, p. 3-42.

${ }^{15}$ S. Rabelo, Long-Run Policy Analysis and Long-Run Growth, Journal of Political Economy, 99, 1991, p. 500-521.

${ }^{16}$ More in: Ph. Aghion, P.W. Howitt, The Endogenous Growth Theory, MIT Press, Cambridge 1998.

17 O. Galor, D.N. Weil, Population, Technology and Growth, American Economic Review, 90(4), 2000, p. 806-828.

${ }^{18}$ More in: P. Annoni, L. Dijkstra, EU Regional Competitiveness Index 2013, Publications Office of the European Union Luxembourg 2013.

${ }^{19}$ More in: E. Diener, S. Eunkook, Measuring quality of life: Economic, social, and subjective indicators, Social Indicators Research, 40(1-2), 1997, p. 189-216, S. Vyas, L. Kumaranayake, Constructing socio-economic status indices: how to use principal components analysis, Health Policy and Planning 21(6), 2006, p. 459-468, A.S. Bhalla, S. Ajit, A.G. Fluitman, Science and technology indicators and socio-economic development, World Development, 13(2), 1985, p. 177-
} 
One of the key factors influencing the pace of development is the quality of strategic management. R. Krupski defines strategic management as "the process of defining and redefining the strategy in response to changes in the environment, overtaking these changes, or even inducing them, coupled with the implementation process in which resources and organization skills are disposed in a way to realize the adopted long-term development goals and to secure the existence of an organization (...)" ${ }^{\prime 20}$. Generally speaking, this process includes the following steps: (a) strategic analysis, (b) planning, (c) implementation ${ }^{21}$.

In countries with a relatively high level of decentralization of territorial systems (such as Poland) responsibility for these processes lies with the institutions of territorial administration. Obviously, general conditions for the activity of citizens or organizations are determined by national policies (e.g. legal system, taxes, etc.) or global trends. However, such elements of the environment as the infrastructure (roads, municipal infrastructure, spatial planning, business environment, education, etc.) depend on local or regional policies. Thus, public administration institutions affect many areas of socioeconomic development. It is necessary to identify the full spectrum of possible dimensions that make up the quality of human life or business development at a local or regional level. Since there are many factors to analyze, it is convenient to use multi-criteria analysis, such as the above-mentioned AHP method. The results will allow improving the quality of decision-making in strategic management by providing systematic and aggregated strategic information ${ }^{22}$. The next sections of this article present and discuss the real-life context of implementation of the AHP method in the process of strategic management in one of the local public administration offices in Poland.

\section{METHODOLOGICAL ASPECTS OF THE RESEARCH - STEPS IN THE AHP ANALYSIS}

This paper presents a selected part of the study conducted in one of the districts of Southern Poland, Nowy Targ, on the occasion of the implementation of the AHP method as part of strategic management. The study focuses on one of the analytical models used in the process of creating a strategy: the prioritization of elements of "endogenous potential" of the district, as explained earlier. Therefore, the objectives and research questions were limited to those related directly to the model. The main objective was to identify those areas of strategic intervention that are the most relevant from the point of view of the investigated district. The following main research question was formulated:

190, E.B. Barbier, The concept of sustainable economic development, Environmental Conservation, 14(02), 1987, p. 101-110.

20 R. Krupski, Zarzqdzanie strategiczne. Koncepcje - metody, Akademia Ekonomiczna we Wrocławiu, Wrocław 2007, p. 97.

21 More in: G. Dess, A. Miller, Strategic Management, McGraw-Hill, New York 1993, G. Gierszewska, M. Romanowska, Analiza strategiczna przedsiębiorstwa, Polskie Wydawnictwo Ekonomiczne, Warsaw1997.

${ }^{22}$ R. Ginevičius, V. Podvezko, Evaluating the changes in economic and social development of Lithuanian counties by multiple criteria methods, Technological and Economic Development of Economy, (3), 2009, p. 418-436, V. Podvezko, Application of AHP technique. Journal of Business Economics and Management, (2), 2009, p. 181-189, P. Ptaszek, W. Adamus, Modele rozwoju gmin w ujęciu wielokryterialnego procesu decyzyjnego, Studia Regionalne i Lokalne, 49(3), 2012, p. 85106. 
- MQ. Which areas of endogenous potential of the Nowy Targ district require special strategic influence because of their impact on the local development processes?

To analyze this research problem, it is worth to answer some specific research questions as follows:

- Q.1: How to describe the endogenous potential of the Nowy Targ district?

- Q.2: How to assess the importance of the identified components of endogenous potential?

- Q.3: How to translate the results of the analysis (significance of the elements of endogenous potential) to the process of programming development?

To analyze these questions the AHP method was used, which allowed both, to construct the endogenous potential model and to choose priorities on the basis of it. As this is a decisionmaking method, it requires selecting a group of experts. There were 14 of them in the research described. All members were responsible for making key decisions in planning and implementation of district strategies, specifically: District Head, District Secretary, District Treasurer and managers of several departments of the Office. The AHP analysis was conducted as part of one of their regular, common meetings. Their opinions and the analysis of public administration tasks, described in Acts were also compared to the theoretic approaches devoted to the analysis of the development process. It was a foundation for an AHP model of endogenic potential. Then, the mentioned group of experts judged elements of this model and chose priorities for the strategic management. Below, there are described steps of the research, especially the process of data collection.

The AHP method allows decomposing complex problems into a hierarchical structure (model) consisting of several levels: the goal (at the top of the hierarchy), criteria/subcriteria and decision variants (alternatives, at the bottom of the hierarchy). Therefore, to answer the first question $(Q .1)$ the AHP model was constructed. The elements of the AHP model have been identified based on two sources, specifically:

- relevant documents concerning public administration in Poland, such: Municipality Act ${ }^{23}$, District Act $t^{24}$, Voivoship Act ${ }^{25}$

- focus group interviews followed by the consultation of the group of experts mentioned above.

The construction of the model takes into account that the development process is understood as a positive change in any area of endogenic potential. Consequently, it is necessary to remember that the identified elements of endogenous potential should describe as comprehensively as possible the entire spectrum of socioeconomic, environmental and anthropogenic dimensions of a local government unit. The model describing the endogenous potential should be universal enough to be used in strategic analysis to assess the situation of the district. Hence, the elements at the lower level of the hierarchy (subcriteria) should be measurable and available for use in the process of strategic benchmarking. Therefore, they require relevant data (i.e. official statistics) that can be used in the assessment of the model. Obviously, there must be instruments by which the government is able to carry the strategic intervention alone or with support of lower-level administrative units (in the case of the district, these lower-level units are municipalities).

\footnotetext{
${ }^{23}$ District Act, Parliment, Warsaw 1998.

${ }^{24}$ Municipality Act, Parliment, Warsaw 1990.

${ }^{25}$ Voivodship Act, Parliment, Warsaw 1998.
} 
The second question $(Q .2)$ concerns procedural and methodological issues. In Poland, strategies are generally created with the use of the so-called social approach, which is based on the participation of various social groups in the decision process. However, decision-making process in this area would require more expert approach. Prioritization should therefore take place in a group of people who have appropriate information as regards the territorial government unit, who have access to the relevant data and know legal restrictions of the strategic intervention. Thus, the authors decided to modify the procedure of building the strategy in such a way that public consultation did not concern the priorities, but rather specific projects that make up the target strategic intervention within priorities selected by the experts.

Generally, experts from a District Office in Nowy Targ were asked to assess, which dimension and which element of the dimension is important from the point of view of longterm development in this district. Only focusing on priorities is an effective way to achieve strategic goals in conditions of limited financial possibilities. The procedure of AHP comparable analysis seems to be very useful here. At the beginning, researchers-moderators provided some explanations about the AHP method and specificity of pairwise comparisons. The AHP presentation lasted about 1 hour, including questions from the participants. The above mentioned group of decision-makers completed pairwise comparisons for each level of the model, using the bipolar 9-point fundamental scale, from "1" indicating the same importance/preference of two elements A and B, to "9" which corresponds to the extreme dominance of A over B (or B over A, respectively). The input of the comparisons is placed into square matrices, and priorities (local and global) are calculated.

Since a majority of real-life decisions is made in the group settings, individual judgments are aggregated into the common, group priorities. A problem appeared as regards the aggregation of individual responses. There are two ways of aggregating individual AHP outcomes in a group-based decisions: AIJ (Aggregation of Individual Judgments) and AIP (Aggregation of Individual Priorities). Although the consensus-based AIJ was more appropriate for a uniform group, they preferred to complete the questionnaires individually. Subsequently, individual models were constructed and AIP procedure was applied using arithmetic mean. The choice of a procedure depends on whether the group acts together as a unit or as separate individuals. The AIJ is the most appropriate when the group acts in synergy, while AIP is used to aggregate final priorities of independent respondents. In the two cases, both geometric and arithmetic means are used for aggregating the results (Forman \& Peniwati, 1998). Alongside calculating priorities, the AHP requires testing consistency of pairwise comparisons. The consistency test is based on the consistency ratio (CR), which allows a certain level of acceptable deviations $(C R<0,1)$. When a pairwise comparison matrix fails to satisfy the consistency requirement, revisions have to be made by the respondents ${ }^{26}$. The whole process beginning from proper construction of the hierarchy, pairwise comparisons, calculating and aggregating the priorities has been explained in detail in many publications by T.L. Saaty ${ }^{27}$ or other authors, like A. Prusak i P. Stefanów ${ }^{28}$. Thus, these issues will not be

\footnotetext{
${ }^{26}$ A. Prusak, P. Stefanów, P. Badania nad wtaściwościami operacyjnymi metody AHP, Folia Oeconomica Cracoviensia, 52, 2011, 87-104.

27 T.L. Saaty, Fundamentals of Decision Making and Priority Theory with the Analytic Hierarchy Process (2nd ed.), RWS Publications, Pittsburg 2000.

28 A. Prusak, P. Stefanów, AHP - analityczny proces hierarchiczny. Budowa i analiza modeli decyzyjnych krok po kroku (1st ed.), C.H. Beck, Warsaw 2014
} 
further explained in this paper, which focuses on practical aspects of the implementation of the AHP in real-life decision-making processes

Third question $(Q .3)$ takes into account the fact that the decision-making process involves the selection of appropriate tools influencing the endogenous potential. There is a fundamental problem associated with the need to match the planned intervention into the legal framework limiting the operation of the local government level. Regions, districts and municipalities have statutorily defined responsibilities (tasks). It determines the structure of not only income, but also expenses and employee involvement in certain activities. Selection of priorities requires focusing only on important issues, which can be difficult due to legal restrictions. Therefore, the AHP methods have been combined with Project Management, by referring to development programs and projects. Consequently, the strategic budget has been separated as part of general budgets developed during implementation of the adopted strategy. Strategic budget consists of measures that can be used for activities in certain strategic priorities.

\section{RESEARCH RESULTS - MODEL AND DATA ANALYSIS}

The procedure of AHP helped to achieve the model of endogenic potential and the rank of elements of it. The complete hierarchical model is presented in Figure 1. It covers four dimensions of endogenic potential (criteria), that is: the potential of the society, the potential of the economy, the potential of the environment and the potential of institutions. All of them have also the more detailed areas (sub-criteria).

Figure 1. The AHP model of factors influencing local development in Poland at the district level.

\begin{tabular}{|c|c|c|c|}
\hline \multicolumn{4}{|c|}{ ENDOGENIC POTENTIAL } \\
\hline $\begin{array}{l}\text { POTENTIAL OF } \\
\text { SOCIETY }\end{array}$ & $\begin{array}{l}\text { POTENTIAL OF } \\
\text { ECONOMY }\end{array}$ & $\begin{array}{l}\text { POTENTIAL OF } \\
\text { ENVIRONMENT }\end{array}$ & $\begin{array}{l}\text { POTENTIAL OF } \\
\text { INSTITUTIONS }\end{array}$ \\
\hline Social capital & Entrepreneurship & Anthropogenic potential & Competencies of workers \\
\hline Citizenship & Innovativeness & Communication infrastr. & Efficiency and effectiv. \\
\hline Cooperation & Innovation in business & Municipal infrastr. & \\
\hline Trust & Research and develop. & Tourism infrastr. & \\
\hline Human capital & Production potential & Healthcare infrastr. & \\
\hline Demographic potential & Staff & Educational infrastr. & \\
\hline Structure and level & Companies & Cultural infrastructure & \\
\hline & Agriculture & Social care infrastr. & \\
\hline & & Natural environment & \\
\hline & & Cleanness & \\
\hline & & Tourist attractions & \\
\hline & & Natural resources & \\
\hline
\end{tabular}

Source: own research.

Tabela 1. Characteristics of the main elements of the endogenous potential model.

\begin{tabular}{|c|c|}
\hline Term & Definition \\
\hline \multicolumn{2}{|r|}{ Criteria level } \\
\hline Potential of society & $\begin{array}{l}\text { Characteristics of the citizens of the district, including competencies, } \\
\text { relationships and demographic potential }\end{array}$ \\
\hline Potential of economy & $\begin{array}{l}\text { Characteristics of the private sector, including production potential, } \\
\text { innovativeness and entrepreneurship }\end{array}$ \\
\hline Potential of environment & $\begin{array}{l}\text { Natural resources and infrastructure, determining quality of life as well as } \\
\text { conditions for tourism, agriculture and mining }\end{array}$ \\
\hline Potential of institutions & $\begin{array}{l}\text { Characteristics of public administration, including competencies and the quality } \\
\text { of work }\end{array}$ \\
\hline
\end{tabular}




\begin{tabular}{|c|c|}
\hline Social capital & $\begin{array}{l}\text { Features of the society allowing the formation of interpersonal relations, } \\
\text { including: } \\
\text { - Citizenship - behavior associated with political and civil activity, including } \\
\text { participation in democratic elections, } \\
\text { - Cooperation - ability to work with different dimensions within cultural } \\
\text { associations, NGOs, etc., } \\
\text { - } \quad \text { Trust - level of trust, especially in economic relations. }\end{array}$ \\
\hline Human capital & $\begin{array}{l}\text { Features of the society, influencing on the quality of the society activity in many } \\
\text { areas, including: } \\
\text { - Demographic potential - demographic structure of the society and ability to } \\
\text { generate positive birthrate, } \\
\text { - Structure and level of competence - the knowledge and skills of people } \\
\text { living in the district. }\end{array}$ \\
\hline Entrepreneurship & Formation and development of businesses, particularly SMEs \\
\hline Innovation & $\begin{array}{l}\text { Creation of inventions in various } \mathrm{R} \& \mathrm{D} \text { institutions and innovations (product, } \\
\text { process, etc.). It involves: } \\
-\quad \text { Innovation in business - ability of enterprises to create and implement } \\
\text { innovations, } \\
\text { - Research and development - the ability of the R\&D institutions to generate } \\
\text { new inventions. }\end{array}$ \\
\hline Production potential & $\begin{array}{l}\text { The production potential of the economic system, assessed quantitatively and } \\
\text { involving human, business, and agricultural resources. It consists of: } \\
\text { - Staff - number of available human resources in working-age population and } \\
\text { number of employed, } \\
\text { - Companies - number and size of economic entities, } \\
\text { - } \quad \text { Agriculture - number and size of agricultural resources. }\end{array}$ \\
\hline Anthropogenic potential & $\begin{array}{l}\text { Elements of the environment created by human, and constituting technical } \\
\text { infrastructure of the economic system. They include: } \\
\text { - Communication infrastructure - quality and number of roads and railways, } \\
\text { - Municipal infrastructure - infrastructure related to the management of municipal } \\
\text { waste or sewage, } \\
\text { - Tourism infrastructure - including in particular tourist attractions and } \\
\text { accommodation services, } \\
\text { - Healthcare infrastructure - infrastructure of the health care system, i.e. hospitals, } \\
\text { medical centers, } \\
\text { - Educational infrastructure - infrastructure supporting the provision of } \\
\text { educational services, including buildings, equipment, etc. } \\
\text { - Cultural infrastructure - infrastructure supporting the provision of cultural } \\
\text { services, such as theatres, community centers etc. } \\
\text { - Social care infrastructure - infrastructure for providing services in social care } \\
\text { and assistance. }\end{array}$ \\
\hline Natural environment & $\begin{array}{l}\text { Features of the natural environment of the territory, including: } \\
\text { - Cleanness - features of the natural environment, such as level of pollution, } \\
\text { waste of sewage, } \\
\text { - Tourist attractions - natural tourist attractions, such as lakes, forests, } \\
\text { mountains, monuments of nature, etc., } \\
\text { - Natural resources (renewable and non-renewable) - availability of natural } \\
\text { resources such as forests, water and minerals. }\end{array}$ \\
\hline Competencies of workers & $\begin{array}{l}\text { Competencies of the employees of public administration and especially - } \\
\text { policy-makers. }\end{array}$ \\
\hline Efficiency and effectiveness & $\begin{array}{l}\text { Ability to effective and efficient realization of public administration tasks, as } \\
\text { measured by budget expense indicators }\end{array}$ \\
\hline
\end{tabular}

Source: own research.

All the criteria and subcriteria used in the model are described in Table 1. Description of each element of the model and short definitions is provided. Such definitions were also used 
during the process of judgement by the expert group. Thanks to that all of members could understand each element of the model in the very common way.

The analysis of the priorities of the development, presented in this paper is narrowed to the more detailed elements of the model. Figure 2 shows aggregated, the global priorities of endogenic potential (subcriteria) at the district level. The most important areas of development are those with the highest priorities. They are: Entrepreneurship (10,4\%) followed by Tourist attractions (9,03\%), Demographic potential (8,78\%), Innovation in business (7,92\%), Clean environment $(7,13 \%)$ and Competencies (Competences of workers of public institutions) $(6,65 \%)$. These aspects should constitute the main directions for strategic interventions in the years 2015-2022. The results revealed the need for reducing strategic intervention in a few key areas (those which received the lowest values of priorities), e.g. Educational infrastructure, Municipal infrastructure, Staff (Production potential of the staff), Cultural infrastructure and Social care infrastructure.

Figure 2. The global priorities of factors influencing local development

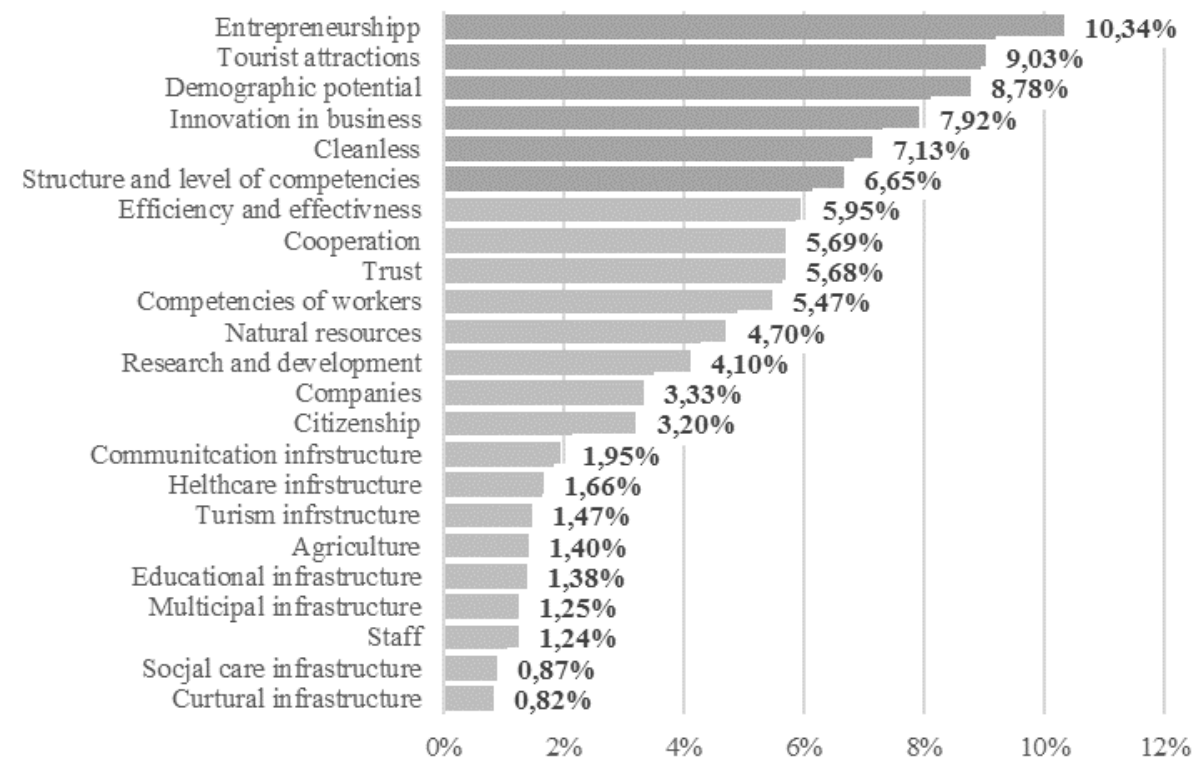

Source: own research.

However, implementing the strategy based on such priorities it is difficult to achieve in practice for several reasons. First, part of the funding sources available for public administration can only be used for selected activities. Thus, it is impossible to construct a flexible strategic budget. Second, it was difficult to decide which elements will be included in the set of strategic priorities. Following the discussions, first six elements of the ranking of endogenous potential entered into the set of strategic priorities. It seems that the number of priority areas for intervention cannot be limited arbitrarily. It is necessary to analyze the results and understand the decision individually for each administrative unit at a time.

The decision-making process has also become an opportunity to observe other limitations and problems associated with the implementation of the AHP in public administration (and, more broadly, in real-life decision making processes that may happen in any organization). 
One of them was difficult to obtain the consistent judgments from all the respondents. As mentioned above, consistency was measured using Consistency Ratio (CR), which cannot exceed 0,1 (10\%) (see: Introduction). It forced us to exclude several questionnaires from the analysis. Another limitation was the disagreement of the respondents on data collection procedure - whether judgments are to be expressed collectively and aggregated using AIJ procedure, or independently (AIP procedure). As most of them preferred to fill in the AHP questionnaires independently, the AIP was finally used, although the group was rather homogenous, implying that reaching the consensus might be a better solution (see: Introduction).

Last but not least, it was difficult to implement the results in a real-life strategy of local development due to the previous commitments made prior to the AHP study. The solution was to move into a tactical level (development programs). Following identification of these programs, we analyzed the possibilities of realization of particular projects addressed to specific areas of endogenous potential. The priorities were reflected in the importance of particular development programs in the process of strategic intervention. This can be seen not only in the structure of the strategic budget, but also in preparing for the implementation of specific projects, including those co-funded from external sources.

\section{CONCLUSIONS}

The study presented and discussed in this paper was an experiment, which can be used to establish standards of strategic management in public administration in Poland using the AHP method, to increase efficiency and effectiveness of decisions. To our knowledge, it is the first such study implemented in Poland. We failed to find a description of similar examples in the literature (neither Polish nor international journals). Subsequently, the proposed solution can be regarded as innovative and having potentially great significance for the development of the AHP method itself, as well as to improve the quality of strategic management in Polish public administration. Due to its flexibility and versatility, the presented procedure is relatively easy to apply under different cultural or legal conditions, which means that it can be used in many other countries.

As regards the specific research objectives, the following conclusions have been drawn from the study:

1. The AHP model was found helpful in structuring and describing a complex, real-life decision-making problem of local government in Southern Poland district of Nowy Targ: to identify the most important factors influencing local development processes.

2. The highest priority factors (Entrepreneurship, Tourist attractions and Demographic potential) should be the main directions of local development strategy 2015-2022. Subsequently, activities of the District Office should direct particular efforts in these strategic areas, including financial resources.

3. The model and results of the study may serve as a material for comparative analysis with other similar districts and indicate areas for potential improvement.

4. The research allowed identification of the problems related to group decision-making process using the AHP in public administration. One of them was the selection of the respondents (experts).

Referring to the specificity of the AHP method itself, due to the formalization of decisionmaking processes in public administration, this sector may be a great target to benefit from the AHP. Its particular utility is visible at the level of strategic management, serving not only 
strictly for decision-making, but through hierarchization of a decision problem, contributes to the organization of management information. However, in Poland there are a lot of legal and cultural limitations that hinder not just the use of the AHP method itself, yet rather the application of its results in strategic intervention. Due to the obligations imposed on various levels of government, sometimes it is impossible to focus on the priorities defined by the AHP. Thus, the AHP results should be treated as guidelines supporting programming development in certain important areas, rather than as a ,decision-to-be-made" per se. Also, further research is needed on the use of other decision-support methods, such as benchmarking, in combination with the AHP. Such integrated models will allow supplementing the AHP with the detailed statistical data.

It is also worth to point, that all elements used to construct the model should be expanded with the statistical data on the most detailed level. These data need the additional process of assessment of the priorities, using the Saaty's scale. On the basis of it indicators could be calculated to achieve an ability do the time-series analysis and benchmarking analysis of the district situation. Using data permits to asses the initial situation and the direction of change in each area of endogenous potential. This step of the strategic analysis is not encompassed by this paper

\section{REFERENCES}

[1] Aghion Ph., Howitt P.W., The Endogenous Growth Theory, MIT Press, Cambridge 1998.

[2] Annoni P., Dijkstra L., EU Regional Competitiveness Index 2013, Publications Office of the European Union Luxembourg 2013.

[3] Barbier E.B., The concept of sustainable economic development, Environmental Conservation, 14(02), 1987, p. 101-110.

[4] Bhalla A.S., Ajit S., Fluitman A.G., Science and technology indicators and socio-economic development, World Development, 13(2), 1985, p. 177-190.

[5] Central Statistic Office, Area and population in the territorial profile in 2015, CSO, Methodology, Standards and Registers Department Warsaw 2015.

[6] Dess G., Miller A., Strategic Management, McGraw-Hill, New York 1993,

[7] Diener E., Eunkook S., Measuring quality of life: Economic, social, and subjective indicators, Social Indicators Research, 40(1-2), 1997, p. 189-216.

[8] Filipiak B., Efektywność w zarzadzaniu finansami samorzadowymi. Skutek kryzysu czy obiektywna konieczność?, Zeszyty Naukowe, Polskie Towarzystwo Ekonomiczne, (10), 2011, p. 223-236.

[9] Galor O., Weil D.N., Population, Technology and Growth, American Economic Review, 90(4), 2000, p. 806-828.

[10] Gierszewska G., Romanowska M., Analiza strategiczna przedsiębiorstwa, Polskie Wydawnictwo Ekonomiczne, Warsaw1997.

[11] Ginevičius R., Podvezko V., Evaluating the changes in economic and social development of Lithuanian counties by multiple criteria methods, Technological and Economic Development of Economy, (3), 2009, p. 418-436.

[12] Kompa K., Budowa mierników agregatowych do oceny poziomu rozwoju społeczno-gospodarczego, Zeszyty Naukowe SGGW Ekonomika i Organizacja Gospodarki Żywnościowej, 74, 2009. 
[13] Krupski R., Zarzadzanie strategiczne. Koncepcje - metody, Akademia Ekonomiczna we Wrocławiu, Wrocław 2007, p. 97.

[14] Lucas R.E., On the Mechanics of Economic Development, Journal of Monetary Economics, 22, 1988, p. 3-42.

[15] Parilament, District Act, Parliment, Warsaw 1998.

[16] Parilament, Municipality Act, Parliment, Warsaw 1990.

[17] Parilament, Voivodship Act, Parliment, Warsaw 1998.

[18] Parliament, Public Financial Act, Parliament, Warsaw 2009.

[19] Podvezko V., Application of AHP technique. Journal of Business Economics and Management, (2), 2009, p. 181-189.

[20] Prusak A., Stefanów P., Badania nad właściwościami operacyjnymi metody AHP, Folia Oeconomica Cracoviensia, 52, 2011, 87-104.

[21] Prusak A., Strojny J., Stefanów P., Analityczny Proces Hierarchiczny (AHP) na skróty - kluczowe pojęcia i literatura, Humanities and Social Sciences, (4), 2014, p. 179-192.

[22] Prusak, A., Stefanów, P., AHP - analityczny proces hierarchiczny. Budowa $i$ analiza modeli decyzyjnych krok po kroku (1st ed.), C.H. Beck, Warsaw 2014

[23] Ptaszek P., Adamus W., Modele rozwoju gmin $w$ ujęciu wielokryterialnego procesu decyzyjnego, Studia Regionalne i Lokalne, 49(3), 2012, p. 85-106.

[24] Rabelo S., Long-Run Policy Analysis and Long-Run Growth, Journal of Political Economy, 99, 1991, p. 500-521.

[25] Romer P.M., The Origins of Endogenous Growth, Journal of Economic Perspectives, 8, 1994, p. 3-22.

[26] Saaty T.L., Fundamentals of Decision Making and Priority Theory with the Analytic Hierarchy Process (2nd ed.), RWS Publications, Pittsburg 2000.

[27] Saaty T.L., Relative Measurement and Its Generalization in Decision Making. Why Pairwise Comparisons are Central in Mathematics for the Measurement of Intangible Factors The Analytic Hierarchy/Network Process, RACSAM (Revista de La Real Academia de Ciencias Exactes, Fisicas Y Naturales. Serie A. Matematicas), 102(2), 2008, p. 251-318.

[28] Strojny J., Innowacyjne zarzadzanie regionem, powiatem i gmina, Rzeszow University of Technology, Rzeszow 2012.

[29] Tokarski T., Matematyczne modele wzrostu gospodarczego (ujęcie neoklasyczne), Wydawnictwo UJ, Krakow 2009.

[30] Vaidya O.S., Kumar S., Analytic hierarchy process: An overview of applications, European Journal of Operational Research, 169(1), 2006, 1-29.

[31] Vyas S., Kumaranayake L., Constructing socio-economic status indices: how to use principal components analysis, Health Policy and Planning 21(6), 2006, p. 459-468.

\section{IMPLEMENTACJA AHP DO PROCESU ZARZADZANIA STRATEGICZNEGO - CASE STUDY PROCESÓW DECYZYJNYCH W POLSKIEJ ADMINISTRACJI LOKALNEJ}

Nowoczesna gospodarka wymaga ciągłego doskonalenia procesu zarządzania. Odnosi się to nie tylko do biznesu, ale także administracji publicznej. Konieczne jest, aby szukać metod, zapewniających poprawę jakości zarządzania, w tym optymalizację procesów decyzyjnych. Jedną z takich metod wspomagania decyzji jest Analityc Hierarchy Process (AHP), zaproponowany 
przez amerykańskiego matematyka, T.L. Saaty'ego w latach 70-tych. Od tego czasu, metoda ta jest powszechnie stosowane w praktyce. Niniejszy artykuł przedstawia proces budowy i analizy modelu AHP, który wspiera samorząd lokalny (starostwo powiatowe) w identyfikacji czynników priorytetowych zarządzania strategicznego. Wdrożenie odbyło się $\mathrm{w}$ jednym $\mathrm{z}$ powiatów $\mathrm{w}$ południowej Polsce, Nowym Targu. Model odnosi się do zarządzania strategicznego rozwojem lokalnym rozumianym jako zmiany endogenicznego potencjału regionu. Jest zbudowany $\mathrm{z}$ czterech głównych kryteriów: potencjał społeczeństwa, potencjał gospodarki, potencjał środowiska i potencjału instytucji (samorządu). Każde kryterium składa się z wielu czynników wpływających (kryteria cząstkowe). Badana grupa decydentów obejmowała 14 osób zatrudnionych w Starostwie Powiatowym w Nowym Targu. Wszystkie z nich są odpowiedzialne za podejmowanie kluczowych decyzji w planowaniu i realizacji strategii powiatowych. Procedurę AIP (Aggregation of Individual Priorities) użyto do agregacji indywidualnych wyników AHP. Priorytety pokazują, że najważniejsze czynniki wpływające na rozwój lokalny na poziomie powiatu są to: przedsiębiorczość, atrakcje turystyczne, potencjał demograficzny, innowacyjność w biznesie, czystość środowiska i kompetencje pracowników samorządowych. Te aspekty powinny być główne kierunki działań strategicznych w latach 2015-2022.

Słowa kluczowe: administracja publiczna, strategiczne zarządzanie, AHP.

DOI:10.7862/rz.2015.hss.55

Przesłano do redakcji: październik 2015

Przyjęto do druku: grudzień 2015 